\title{
Pengaruh likuiditas, profitabilitas dan leverage terhadap agresivitas pajak
}

\author{
Nesa Apriliana \\ Program Studi Manajemen, Fakultas Ekonomi, Universitas Islam Kadiri, Kediri, 64128, Indonesia
}

\begin{tabular}{|c|c|}
\hline INFO ARTIKEL & ABSTRAK \\
\hline $\begin{array}{l}\text { Kata kunci: } \\
\text { Likuiditas, profitabilitas, } \\
\text { leverage, agresivitas } \\
\text { pajak }\end{array}$ & $\begin{array}{l}\text { Penelitian ini bertujuan untuk mengetahui pengaruh likuiditas, } \\
\text { profitabilitas, dan leverage terhadap agresivitas pajak. Variabel } \\
\text { independen yang digunakan meliputi likuiditas, profitabilitas, dan } \\
\text { leverage sedangkan agresivitas pajak sebagai variabel dependen. } \\
\text { Populasi yang digunakan dalam penelitian ini adalah laporan keuangan } \\
\text { tahunan perusahaan manufaktur sub sektor food and beverage yang } \\
\text { terdaftar di Bursa Efek Indonesia tahun } 2011-2018 \text { yang berjumlah } 11 \\
\text { perusahaan. Teknik pengambilan sampel pada penelitian ini } \\
\text { menggunakan metode purposive sampling (Penentuan sampel } \\
\text { menggunakan kriteria tertentu) dan diperoleh sampel sebanyak } 9 \\
\text { perusahaan manufaktur sub sektor food and beverage. Metode yang } \\
\text { digunakan pada penelitian ini meliputi analisis statistik deskriptif, uji } \\
\text { asumsi klasik, analisis regresi linier berganda. Hasil penelitian yang } \\
\text { dilakukan menunjukkan bahwa diantara variabel likuiditas, } \\
\text { profitabilitas, dan leverage yang berpengaruh terhadap agresivitas } \\
\text { pajak adalah variabel likuiditas. }\end{array}$ \\
\hline
\end{tabular}

\begin{tabular}{ll}
\hline ARTICLE INFO & ABSTRACT \\
\hline Keywords: & Thiquidity, profitability, \\
leverage, tax & leverage on tax aggressiveness. The independent variables used include \\
aggressiveness & $\begin{array}{l}\text { liquidity, profitability, and leverage, while tax aggressiveness as the } \\
\text { dependent variable. The population used in this study is the annual } \\
\text { financial statements of the food and beverage sub-sector } \\
\text { manufacturing companies listed on the Indonesia Stock Exchange from } \\
2011 \text { to 2018, totaling } 11 \text { companies. The sampling technique in this } \\
\text { study used a purposive sampling method (determination of the sample } \\
\text { using certain criteria) and obtained a sample of } 9 \text { manufacturing } \\
\text { companies in the food and beverage sub-sector. The method used in } \\
\text { this study includes descriptive statistical analysis, classical assumption } \\
\text { tests, multiple linear regression analysis. The results of the research } \\
\text { conducted indicate that among the variables of liquidity, profitability, } \\
\text { and leverage that affect tax aggressiveness is the liquidity variable. }\end{array}$ \\
\end{tabular}

Korespondensi Penulis: Program Studi Manajemen Fakultas Ekonomi, Universitas Islam Kadiri, Jalan Sersan Suharmadji No. 38, Manisrenggo, Kediri 64128, Indonesia. E-mail: apriliananesa@gmail.com 


\section{Pendahuluan}

Di Indonesia, pajak merupakan sumber dana terbesar bagi negara. Pajak wajib dibayarkan oleh wajib pajak pribadi maupun wajib pajak badan. Dalam Undang - Undang Nomor 36 Tahun 2008 pasal 2 ayat (1), perusahaan merupakan wajib pajak badan yang memiliki kewajiban untuk membayar pajak sesuai dengan ketentuan perpajakan yang dihitung dari besarnya laba bersih sebelum pajak dikalikan dengan tarif pajak yang berlaku (Mardiasmo, 2008).

Semakin besar pajak yang dibayarkan oleh perusahaan maka semakin besar penerimaan negara dari sektor pajak. Sebaliknya bagi perusahaan, pajak merupakan beban yang harus ditanggung dan dapat mengurangi laba bersih yang diterima perusahaan. Dalam penelitian terdahulu seperti Suyanto dan Supramono (2012) yang mencoba mengaitkan kondisi keuangan perusahaan dengan akivitas pajak, antara lain pada tingkat likuiditas perusahaan, profitabilitas, dan leverage.

Kemampuan perusahaan untuk melaksanakan kewajiban jangka pendek dapat dilihat dari rasio likuiditas. Apabila rasio likuiditas tinggi maka perusahaan tersebut berada dalam kondisi arus kas yang lancar. Perusahaan yang mengalami kesulitan likuiditas kemungkinan tidak akan mematuhi peraturan perpajakan dan akan mengurangi pengeluaran perusahaan atas pajaknya (Sukmawati dan Rebecca, 2016).

Profitabilitas merupakan kemampuan perusahaan dalam memperoleh laba. Return On
Asset (ROA) adalah salah satu rasio yang menggambarkan profitabilitas perusahaan. Return On Asset (ROA) yang positif menunjukkan bahwa total aktiva yang digunakan untuk aktivitas perusahaan mampu memberikan laba. Profitabilitas merupakan faktor penentu beban pajak, karena perusahaan dengan laba yang besar akan dikenakan pajak yang besar pula (Kurniasih dan Ratna Sari, 2013).

Leverage merupakan rasio yang mengukur kemampuan hutang baik jangka panjang maupun jangka pendek untuk membiayai aset perusahaan. Hutang bagi perusahaan memiliki beban tetap yang berupa beban bunga. Perusahaan yang memiliki hutang tinggi akan mendapatkan insentif pajak berupa potongan atas bunga pinjaman sehingga perusahaan yang memiliki beban pajak tinggi dapat melakukan penghematan pajak dengan cara menambah hutang perusahaan (Suyanto dan Supramono, 2012).

Penelitian ini memberikan hasil terbaru dari penelitian - penelitian terdahulu yang sudah ada seperti yang dilakukan oleh Fadli et al. (2016), dan Purwanto et al. (2016) menguji pengaruh terhadap agresivitas pajak. Tujuan penelitian untuk menguji pengaruh likuditas, profitabilitas, dan leverage terhadap agresivitas pajak perusahaan manufaktur sub sektor food and beverage tahun 2011-2018.

\section{Tinjauan Pustaka dan Pengembangan Hipotesis}

2.1 The trend-off theory dan The pecking order theory 
Teori ini menyatakan bahwa perusahaan akan memilih leverage yang optimal setelah membandingkan keuntungan dan kerugian yang akan diperoleh dengan dana pinjaman. Teori trade-off adalah teori bahwa perusahaan memilih berapa banyak pembiayaan utang dan berapa banyak pembiayaan ekuitas yang akan digunakan dengan menyeimbangkan biaya dan manfaat. Kraus dan Litzenberger (1973) mempertimbangkan keseimbangan antara biaya bobot mati kebangkrutan dan manfaat penghematan pajak dari utang.

Seringkali biaya agensi juga termasuk dalam saldo. Teori ini sering dijadikan sebagai teori pesaing terhadap teori pecking order dari struktur modal (Frank \& Goyal, 2011). Tujuan penting dari teori ini adalah untuk menjelaskan fakta bahwa perusahaan biasanya dibiayai sebagian dengan utang dan sebagian dengan ekuitas. Ini menyatakan bahwa ada keuntungan untuk pembiayaan dengan utang, manfaat pajak dari utang dan ada biaya pembiayaan dengan utang, biaya kesulitan keuangan termasuk biaya kebangkrutan utang dan biaya nonkebangkrutan (misalnya meninggalkan staf, pemasok menuntut kerugian syarat pembayaran, pertikaian pemegang obligasi/pemegang saham, dll.).

\subsection{Likuiditas}

Likuiditas adalah kemampuan perusahaan dalam memenuhi kewajiban jangka pendek. Pada penelitian ini, rasio yang digunakan sebagai alat ukur likuiditas adalah rasio lancar (current ratio), karena rasio lancar merupakan rasio yang digunakan untuk mengukur kemampuan perusahaan dalam memenuhi kewajiban jangka pendek dengan melihat aktiva lancar perusahaan terhadap hutang lancarnya. Dalam hal ini hutang adalah kewajiban perusahaan yang salah satunya adalah hutang pajak.

\subsection{Profitabilitas}

Profitabilitas merupakan indikator kinerja yang dilakukan manajemen dalam mengelola kekayaan perusahaan yang ditunjukkan dengan laba yang dihasilkan. Dalam penelitian ini rasio profitabilitas diukur menggunakan Return On Asset (ROA). Alasan peneliti memilih Return On Asset (ROA) sebagai alat ukur profitabilitas karena setiap laba yang dihasilkan perusahaan memiliki beban pajak.

\subsection{Leverage}

Nugraha dan Meiranto

mendefinisikan leverage sebagai penggunaaan aset atau dana yang penggunaannya memiliki kewajiban untuk membayar biaya tetap. Leverage ada apabila perusahaan menggunakan dana pinjaman yang memiliki beban bunga untuk digunakan pada pembiayaan aset perusahaan.

Pada penelitian ini, alat ukur yang digunakan untuk mengetahui leverage pada perusahaan adalah Debt to Asset Ratio (DAR) atau rasio total hutang yang membandingan total kewajiban perusahaan dan total aset perusahaan.

\subsection{Agresivitas Pajak}

Menurut Mustika et al. (2017), agresivitas pajak adalah tindakan yang dilakukan oleh perusahaan untuk mengurangi pendapatan kena 
pajak yang dilakukan melalui perencanaan pajak (tax planning) baik dengan cara legal yaitu melakukan penghindaran pajak (tax avoidance) maupun dengan cara ilegal yang dilakukan dengan penggelapan pajak (tax evasion) dengan memanfaatkan celah-celah yang ada dalam peraturan perpajakan.

Pada penelitian ini alat ukur yang digunakan untuk mengetahui kegiatan agresivitas pajak adalah Effective Tax Rate (ETR). Semakin rendah nilai ETR mengindikasikan bahwa adanya agresivitas pajak dalam perusahaan.

\subsection{Likuiditas dan Agresivitas Pajak}

Likuiditas mengukur kemampuan perusahaan dalam memenuhi kewajiban jangka pendek (Hanafi dan Halim, 2016). Semakin tinggi rasio likuiditas perusahaan menandakan perusahaan tersebut dalam keadaan sehat. Terdapat beberapa penelitian terdahulu yang meneliti pengaruh likuiditas terhadap agresivitas pajak antara lain penelitian yang dilakukan oleh Purwanto et al. (2016) membuktikan bahwa perusahaan dengan likuiditas yang baik akan memiliki tingkat agresivitas pajak yang rendah dan apabila likuiditas perusahaan buruk dapat diindikasikan bahwa tingkat agresivitas pajak pada perusahaan tinggi.

Penelitian yang dilakukan oleh Suyanto dan Supramono (2012) memberikan bukti bahwa perusahaan yang mengalami kesulitan likuiditas akan cenderung melakukan penghindaran pajak. Tindakan ini dilakukan oleh perusahaan untuk mengurangi pengeluaran atas pajak dan memanfaatkan penghematan yang dilakukan untuk mempertahankan arus kas. Penelitian yang dilakukan oleh Sukmawati dan Rebecca (2016) yang mendapatkan hasil bahwa likuiditas memiliki pengaruh positif dan signifikan terhadap agresivitas pajak perusahaan. Hal tersebut dikarenakan rasio likuiditas cenderung turun, yang berarti kemampuan perusahaan dalam memenuhi kewajiban jangka pendeknya juga menurun.

Pada penelitian yang dilakukan oleh Putri (2019) menemukan adanya pengaruh likuiditas terhadap tingkat agresivitas pajak. Semakin tinggi rasio likuiditas perusahaan menandakan perusahaan tersebut dalam keadaan yang sehat. Dengan tingginya rasio likuiditas perusahaan, maka tindakan untuk mengurangi laba akan semakin tinggi dengan alasan menghindari beban pajak yang lebih tinggi. Dengan semakin tingginya rasio likuiditas, maka akan berbanding positif dengan tingkat agresivitas pajak perusahaan.

Dari penjelasan diatas dapat diketahui bahwa dengan tingkat likuiditas yang tinggi berarti perusahaan tersebut seharusnya lancar dalam membayarkan kewajiban jangka pendeknya, akan tetapi perusahaan lebih menginginkan pembayaran pajaknya sedikit sehingga melakukan tindakan agresivitas pajak. Dalam hal tersebut dapat dikatakan bahwa likuiditas berpengaruh positif terhadap agresivitas pajak perusahaan.

Hipotesis 1. Likuiditas berpengaruh positif terhadap agresivitas pajak. 


\subsection{Profitabilitas dan Agresivitas Pajak}

Profitabilitas adalah suatu indikator kinerja manajemen dalam mengelola kekayaan perusahaan yang ditunjukkan oleh laba yang dihasilkan. Profitabilitas menunjukkan kinerja keuangan perusahaan dalam menghasilkan laba dari pengelolaan aktiva. Dewinta dan Setiawan (2016), menyatakan bahwa semakin tinggi Return on Asset (ROA) maka semakin besar laba yang diperoleh perusahaan, sehingga pajak yang dibebankan perusahaan akan semakin tinggi dan keadaan tersebut dapat memicu tindakan agresivitas pajak.

Napitu dan Kurniawan (2016) mengemukakan bahwa perusahaan yang mempunyai kemampuan untuk medapatkan keuntungan harus membayar pajak sebesar pendapatan yang diperoleh. Jadi, semakin besar laba yang diperoleh perusahaan maka besar pajak yang harus dibayarkan akan semakin tinggi, sehingga tindakan agresif terhadap pajak akan semakin meningkat.

Hipotesis 2. Profitabilitas berpengaruh positif terhadap agresivitas pajak.

\subsection{Leverage dan Agresivitas Pajak}

Leverage adalah keadaan bagaimana perusahaan dapat memenuhi kewajiban jangka panjangnya. Peminjaman hutang dilakukan perusahaan untuk menutup pendanaan lain yang tidak didanai. Menurut Nugraha dan Meiranto (2015), perusahaan dengan jumlah hutang yang lebih banyak akan memiliki nilai ETR yang lebih rendah. Semakin besar hutang perusahaan maka beban pajak akan menjadi lebih kecil karena bertambahnya unsur biaya usaha dan pengurangan tersebut sangat berarti bagi perusahaan yang pajaknya tinggi. Menurut Purwanto et al. (2016), Perusahaan yang memiliki tingkat leverage tinggi, maka tingkat agesivitas pajaknya akan tinggi, sebaliknya jika tingkat leveragenya rendah maka agresivitas pajaknya akan rendah.

Gunde et all (2017) menyatakan bahwa Debt to Asset Ratio (DER) merupakan rasio yang digunakan untuk mengukur sejauh mana aset perusahaan dibiayai dengan hutang. Perusahaan dimungkinkan menggunakan hutang untuk memenuhi kebutuhan operasional dan investasi perusahaan. Akan tetapi, hutang akan menimbulkan beban tetap (fixed rate ofreturn) bagi perusahaan yang disebut dengan bunga. Perusahaan yang memiliki hutang tinggi akan mendapatkan insentif pajak berupa potongan atas bunga pinjaman sehingga perusahaan yang memiliki beban pajak tinggi dapat melakukan penghematan pajak dengan cara menambah hutang perusahaan (Suyanto dan Supramono, 2012).

Hipotesis 3. Leverage berpengaruh positif terhadap agresivitas pajak.

\subsection{Model Penelitian}

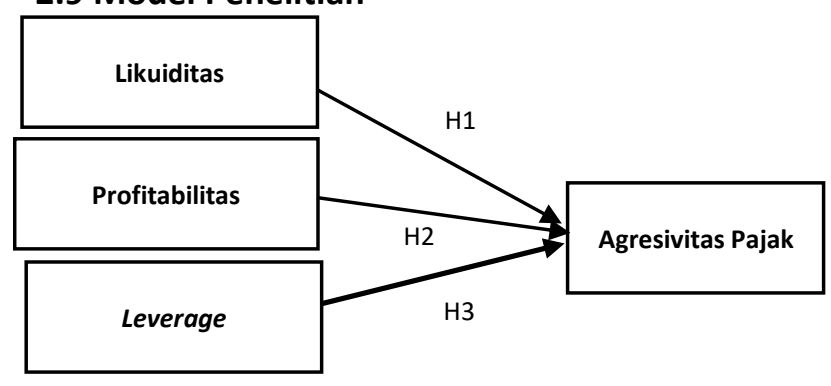

Gambar 1. Model Penelitian 
Dari pembentukan hipotesis dibuat model penelitian pada Gambar. 1.

\section{Metodologi}

\subsection{Jenis Penelitian}

Jenis penelitian ini adalah penelitian kuantitatif, dimana data yang disajikan dalam bentuk angka dan dapat diukur serta diuji dengan metode statistik. Data yang digunakan pada penelitian ini merupakan data laporan keuangan tahunan perusahaan manufaktur sub sektor food and beverage yang terdaftar di Bursa Efek Indonesia (BEI) tahun 2011-2018.

\subsection{Populasi dan Sampel}

Populasi dalam penelitian ini adalah seluruh laporan keuangan perusahaan manufaktur sub sektor food and beverage yang terdaftar di Bursa Efek Indonesia (BEI) periode tahun 2011-2018. Pemilihan periode tujuh tahun bertujuan untuk dapat membandingkan keadaan keuangan perusahaan selama tujuh tahun tersebut dan dapat memperoleh hasil yang dapat menjelaskan permasalahan dalam penelitian ini. Perusahaan non keuangan dipilih karena perusahaan non keuangan mencakup tiga jenis umum perusahaan, yaitu perusahaan manufaktur, perusahaan dagang, dan perusahaan jasa yang dapat mewakili keseluruhan perusahaan yang ada. Total populasi pada penelitian ini berjumlah sebelas perusahaan sub sektor food and beverage periode tahun 2011-2018.

Teknik pengambilan sampel pada penelitian ini dilakukan dengan metode nonprobability sampling tepatnya purposive sampling yaitu metode pengambilan sampel berdasarkan kriteria-kriteria tertentu. Adapun kriteria yang digunakan untuk memilih sampel pada penelitian ini adalah sebagai berikut: 1)Sampel berasal dari perusahaan manufaktur sub sektor food and beverage yang mempublikasikan laporan keuangan selama tahun 2011-2018 secara lengkap; 2)Perusahaan manufaktur sub sektor food and beverage yang menggunakan laporan keuangan dengan satuan nilai rupiah selama tahun penelitian; 3)Perusahaan manufaktur sub sektor food and beverage yang memiliki laporan keuangan dengan posisi laporan laba rugi mendapatkan laba/tidak rugi selama tahun penelitian.

Dari seluruh populasi, terdapat sembilan perusahaan yang memenuhi kriteria yang digunakan sebagai sampel, data yang didapat dari sembilan perusahaan tersebut bejumlah 72 data. Adapun proses penentuan sampel adalah sebagai berikut:

Tabel 1. Penentuan Jumlah Sampel

\begin{tabular}{|c|c|c|c|c|}
\hline \multirow{2}{*}{ No } & \multirow{2}{*}{ Saham } & \multicolumn{3}{|c|}{ Kriteria } \\
\hline & & 1 & 2 & 3 \\
\hline 1 & ADES & $\checkmark$ & $\checkmark$ & $\checkmark$ \\
\hline 2 & BTEK & $\checkmark$ & $\checkmark$ & $x$ \\
\hline 3 & CEKA & $\checkmark$ & $\checkmark$ & $\sqrt{ }$ \\
\hline 4 & DLTA & $\checkmark$ & $\checkmark$ & $\checkmark$ \\
\hline 5 & ICBP & $\checkmark$ & $\checkmark$ & $\checkmark$ \\
\hline 6 & IIKP & $\checkmark$ & $\checkmark$ & $X$ \\
\hline 7 & INDF & $\checkmark$ & $\checkmark$ & $\checkmark$ \\
\hline 8 & MLBI & $\checkmark$ & $\checkmark$ & $\checkmark$ \\
\hline 9 & MYOR & $\checkmark$ & $\checkmark$ & $\sqrt{ }$ \\
\hline 10 & SKLT & $\checkmark$ & $\checkmark$ & $\checkmark$ \\
\hline 11 & ULTJ & $\checkmark$ & $\checkmark$ & $\checkmark$ \\
\hline & Jumlah & 11 & 11 & 9 \\
\hline
\end{tabular}

Sumber: BEI, 2020 
Tabel 2. Jumlah Sampel

\begin{tabular}{|c|l|c|}
\hline No & \multicolumn{1}{|c|}{ Kriteria } & $\begin{array}{c}\text { Jumlah } \\
\text { Perusahaan }\end{array}$ \\
\hline 1. & $\begin{array}{l}\text { Perusahaan } \\
\text { mempublikasikan laporan } \\
\text { keuangan selama tahun } \\
2011 \text { - 2018. }\end{array}$ & 11 \\
\hline 2. & $\begin{array}{l}\text { Perusahaan yang } \\
\text { menggunakan laporan } \\
\text { keuangan dengan satuan } \\
\text { nilai rupiah selama tahun } \\
\text { penelitian. }\end{array}$ & 11 \\
\hline 3. & $\begin{array}{l}\text { Perusahaan yang memiliki } \\
\text { laporan keuangan dengan } \\
\text { posisi laporan laba rugi } \\
\text { mendapatkan laba/tidak } \\
\text { rugi selama tahun } \\
\text { penelitian. }\end{array}$ & 9 \\
\hline $\begin{array}{l}\text { Jumlah data sampel yang diolah } \\
\text { oleh peneliti selama tahun 2011 } \\
-2018 \text { (9 x 8) }\end{array}$ & 72 \\
\hline
\end{tabular}

Sumber: Peneliti, 2020

\subsection{Definisi Operasional Variabel}

Definisi operasional variabel dalam penelitian ini seperti tabel 3.

Tabel 2. Definisi Operasional Variabel

\begin{tabular}{|c|c|l|}
\hline Variabel & Proksi & \multicolumn{1}{|c|}{ Sumber } \\
\hline $\begin{array}{c}\text { Likuiditas } \\
(\mathrm{X} 1)\end{array}$ & $\mathrm{CR}=\frac{\text { Aktiva lancar }}{\text { Hutang lancar }}$ & $\begin{array}{l}\text { (Sukmawati } \\
\text { \& Rebecca, } \\
2016)\end{array}$ \\
\hline $\begin{array}{c}\text { Profitabilitas } \\
(\mathrm{X} 2)\end{array}$ & $\frac{\text { ROA }=}{\text { Laba bersih stlh pajak }}$ & $\begin{array}{l}\text { (Hanafi \& } \\
\text { Halim, } \\
2016)\end{array}$ \\
\hline $\begin{array}{c}\text { Leverage } \\
(\mathrm{X} 3)\end{array}$ & DAR $=\frac{\text { Total hutang }}{\text { Total aset }}$ & $\begin{array}{l}\text { (Sukmawati } \\
\text { \& Rebecca, } \\
2016)\end{array}$ \\
\hline $\begin{array}{c}\text { Agresivitas } \\
\text { Pajak (Y) }\end{array}$ & ETR $=\frac{\text { Total beban Pph }}{\text { Laba sebelum pjk }}$ & $\begin{array}{l}\text { (Nugraha \& } \\
\text { Meiranto, } \\
2015)\end{array}$ \\
\hline
\end{tabular}

Sumber: Peneliti, 2020

\subsection{Teknik Analisis}

\section{Uji Asumsi Klasik}

Uji asumsi klasik digunakan untuk mengetahui apakah data yang dipakai layak untuk dianalisis, karena tidak semua data dapat dianalisis dengan regresi. Tujuan dari uji asumsi klasik adalah untuk mengetahui apakah hasil estimasi regresi yang dilakukan terbebas dari hal yang mengakibatkan hasil regresi tersebut tidak dapat dipergunakan sebagai dasar untuk menguji hipotesis dan penarikan kesimpulan. Pada penelitian ini menggunakan 4 uji asumsi klasik antara lain uji normalitas, uji multikolinieritas, uji autokorelasi, dan uji heterokedastisitas.

\section{Uji Normalitas}

Uji Normalitas data dimaksudkan untuk menguji apakah data sampel dari populasi berdisribusi normal atau tidak. Uji normalitas yang digunakan dalam penelitian ini yaitu menggunakan uji Kolmogrov-Smirnov dengan ketentuan jika nilai Asymp. Sig. nya kurang dari $5 \%$ atau 0,05, maka dapat dikatakan data berdistribusi tidak normal. Jika nilai Asymp. Sig. nya lebih dari atau sama dengan $5 \%$ atau 0,05 , maka dapat dikatakan data berdistribusi normal.

\section{Uji Multikolinearitas}

Uji multikolinieritas digunakan untuk melihat ada tidaknya hubungan yang kuat atau sempurna antar variabel independen. Uji Multikolinieritas dapat dilihat dari nilai Variance Inflation Factor (VIF). Variabel independen dapat dikatakan tidak terjadi multikolinieritas apabila mempunyai nilai Variance Inflation Factor (VIF) kurang dari 4, sebaliknya apabila nilai Variance Inflation Factor (VIF) lebih dari 4 maka dapat dikatakan terjadi multikolinieritas pada variabel independen.

\section{Uji Autokorelasi}

Uji autokorelasi digunakan untuk mendeteksi hubungan antara error periode yang 
satu dengan error periode yang lain. Untuk data yang bersifat time series, uji ini harus dipenuhi.

Uji autokorelasi dapat dilihat dengan menggunakan uji Runt Test. Pada uji Run Test kriteria yang harus dipenuhi adalah jika nilai Asymp. Sig. kurang dari 0,05 maka terdapat gejala autokorelasi, sebaliknya jika nilai Asymp. Sig. lebih besar dari 0,05 maka tidak terdapat gejala autokorelasi.

\section{Uji Heteroskedastisitas}

Uji heteroskedastisitas digunakan untuk mengetahui kesamaan varians error untuk setiap variabel independen. Pada analisis regresi mensyaratkan terjadinya homokedastisitas. Uji heteroskedastisitas yang dilakukan pada penelitian ini adalah menggunakan uji Park. Adapun kriteria pada penelitian ini adalah jika nilai $\mathrm{F}$ sig. kurang dari $5 \%$ atau 0,05 , maka menunjukkan terjadi heterokedastisitas. Sedangkan jika nilai $\mathrm{F}$ sig. lebih dari atau sama dengan 0,05 maka tidak terjadi heterokedastisitas atau terjadi homokedastisitas.

\section{Analisis Regresi Linier Berganda}

Analisis regresi linier berganda digunakan untuk menguji pengaruh variabel independen yaitu likuiditas (CR), profitabilitas (ROA), dan leverage (DAR) terhadap variabel dependen yaitu agresivitas pajak perusahaan. Persamaan regresi dapat dituliskan sebagai berikut:

$\begin{array}{ll}\mathrm{Y}=\alpha+\beta_{1} \mathrm{X}_{1}+ & \beta_{2} \mathrm{X}_{2}+\beta_{3} \mathrm{X}_{3+} \mathrm{e} \\ \mathrm{Y} & : \text { Agresivitas pajak } \\ \mathrm{X}_{1} & : \text { Likuiditas } \\ \mathrm{X}_{2} & \text { : Profitabilitas } \\ \mathrm{X}_{3} & \text { : Leverage }\end{array}$

$$
\begin{array}{ll}
\alpha & : \text { Konstanta } \\
\beta_{1} . . \beta_{2 . .} \beta_{3} & : \text { Koefisien regresi } \\
\mathrm{e} & : \text { Error }
\end{array}
$$

\section{Uji Hipotesis}

Uji statistik $\mathrm{t}$ digunakan untuk menguji signifikansi koefisien variabel independen dalam memprediksi variabel dependen. Uji t (Parsial) digunakan untuk menunjukkan seberapa jauh variabel independen secara individual dapat menerangkan variabel dependen. Uji statistik $t$ digunakan untuk melihat signifikansi dari pengaruh variabel independen secara individu terhadap variabel dependen dengan menganggap variabel lain bersifat konstan. Pengambilan keputusan pada uji t (Parsial), sebagai berikut : 1) Jika nilai signifikansi $<0,05$ ( $\alpha$ $=5 \%)$ dengan nilai $\mathrm{t}$ hitung $>\mathrm{t}$ tabel maka $\mathrm{HO}$ ditolak dan Ha diterima, dalam arti terdapat pengaruh secara parsial antara variabel independen $(X)$ terhadap variabel dependen $(\mathrm{Y})$, 2)Jika nilai signifikansi $>0,05(\alpha=5 \%)$ dengan nilai t hitung $<\mathrm{t}$ tabel maka $\mathrm{HO}$ diterima dan $\mathrm{Ha}$ ditolak, dalam arti tidak terdapat pengaruh secara parsial antara variabel independen $(X)$ terhadap variabel dependen $(\mathrm{Y})$.

\section{Hasil}

\subsection{Analisis Statistik Deskriptif}

Analisis statistik deskriptif digunakan untuk memberikan gambaran atas variabel yang digunakan yaitu likuiditas, profitabilitas, leverage, dan agresivitas pajak. Berdasarkan penghitungan data yang diolah menggunakan analisis statistik deskriptif, didapat hasil pada tabel 3 sebagai berikut: 
Tabel 3. Statistik Deskriptif

\begin{tabular}{|l|r|r|r|r|r|r|r|}
\hline & \multicolumn{1}{|c|}{$\mathrm{N}$} & Range & Min & Max & Sum & Mean & $\begin{array}{c}\text { Std. } \\
\text { Deviation }\end{array}$ \\
\hline CR & 72 & 8.36 & .51 & 8.87 & 181.04 & 2.5144 & 1.88354 \\
\hline ROA & 72 & .65 & .02 & .67 & 10.63 & .1476 & .12712 \\
\hline DAR & 72 & .61 & .14 & .75 & 31.01 & .4307 & .15422 \\
\hline ETR & 72 & .29 & .06 & .35 & 17.78 & .2469 & .05530 \\
\hline $\begin{array}{l}\text { Valid N } \\
\text { (listwise) }\end{array}$ & 72 & & & & & & \\
\hline
\end{tabular}

Sumber: Data Diolah, 2020

Nilai rata - rata atau mean pada variabel likuiditas (CR) sebesar 2,514, nilai maksimum dan minimum sebesar 8,87 dan 0,51 dengan nilai standar deviasi sebesar 1,884 , nilai range sebesar 8,36, nilai sum dari 72 data sebesar 181,04.

Nilai rata - rata atau mean pada variabel profitabilitas (ROA) sebesar 0,148 , nilai maksimum dan minimum sebesar 0,67 dan 0,02, dengan nilai standar deviasi sebesar 0,127 , nilai range 0,65 , nilai sum dari 72 data sebesar 10,63.

Nilai rata - rata atau mean pada variabel leverage (DAR) sebesar 0,431, nilai maksimum dan minimum sebesar 0,75 dan 0,14 , dengan nilai standar deviasi sebesar 0,154, nilai range 0,61, nilai sum dari 72 data sebesar 31,01.

Nilai rata - rata variabel agresivitas pajak (ETR) sebesar 0,246, nilai maksimum dan minimum sebesar 0,35 dan 0,06 , dengan nilai standar deviasi sebesar 0,055, nilai range 0,29, nilai sum dari 72 data sebesar 17,78 .

\subsection{Hasil Uji Asumsi Klasik}

\section{Hasil Uji Normalitas}

Berdasarkan penghitungan data yang diolah menggunakan uji normalitas, didapat hasil yang disajikan pada tabel 4 dan tabel 5 , sebagai berikut:
Tabel 4. Hasil Uji Normalitas Pertama

\begin{tabular}{|c|c|c|c|c|c|}
\hline \multicolumn{6}{|c|}{ One-Sample Kolmogorov-Smirnov Test } \\
\hline & & CR & ROA & DAR & ETR \\
\hline \multicolumn{2}{|l|}{$\mathrm{N}$} & 72 & 72 & 72 & 72 \\
\hline \multirow{2}{*}{$\begin{array}{l}\text { Normal } \\
\text { Parameters }\end{array}$} & Mean & 2.5144 & .1476 & .4307 & .2469 \\
\hline & $\begin{array}{l}\text { Std. } \\
\text { Deviation }\end{array}$ & 1.88354 & .12712 & .15422 & $\begin{array}{r}.0553 \\
0\end{array}$ \\
\hline \multirow{3}{*}{$\begin{array}{l}\text { Most Extreme } \\
\text { Differences }\end{array}$} & Absolute & .259 & .222 & .118 & .213 \\
\hline & Positive & .259 & .222 & .098 & .144 \\
\hline & Negative & -.144 & -.163 & -.118 & -.213 \\
\hline \multirow{2}{*}{\multicolumn{2}{|c|}{$\begin{array}{l}\text { Kolmogorov-Smirnov Z } \\
\text { Asymp. Sig. (2-tailed) }\end{array}$}} & 2.201 & 1.882 & 1.000 & 1.807 \\
\hline & & .000 & .002 & .270 & .003 \\
\hline
\end{tabular}

Sumber: Data Diolah, 2020

Berdasarkan hasil dari uji normalitas yang menggunakan uji Kolmogorov-Smirnov diatas, ditemukan nilai Kolmogrov-Smirnov dari variabel X1 yaitu likuiditas (CR) sebesar 2,201 dengan Asymp. Sig. 0,000, variabel X2 yaitu profitabilitas (ROA) sebesar 1,882 dengan Asymp. Sig. 0,002, variabel X3 yaitu leverage (DAR) sebesar 1,000 dengan Asymp. Sig. 0,270, dan variabel $Y$ yaitu agresivitas pajak (ETR) sebesar 1,807 dengan Asymp. Sig. 0,003. Pada hasil diatas, dinyatakan data berdistibusi tidak normal karena terdapat variabel yang memiliki nilai Asymp. Sig. dibawah 0,05 yaitu variabel likuiditas (CR), profitabilitas (ROA), dan agresivitas pajak (ETR).

Pada penelitian ini, peneliti menguji ulang menggunakan outlier untuk mengatasi ketidaknormalan data pada uji normalitas dengan cara menghilangkan data yang terdeteksi tidak normal melalui aplikasi SPSS 16.0. Berdasarkan perhitungan data uji normalitas yang menggunakan outlier, didapat hasil seperti tabel 5 . 
Tabel 5. Hasil Uji Normalitas Kedua

\begin{tabular}{|ll|r|r|r|r|}
\hline & & \multicolumn{1}{c|}{ CR } & \multicolumn{1}{c|}{ ROA } & \multicolumn{1}{c|}{ DAR } & \multicolumn{1}{c|}{ ETR } \\
\hline $\mathrm{N}$ & & 38 & 38 & 38 & 38 \\
Normal & Mean & 2.0361 & .0934 & .4582 & .2563 \\
Parameters $^{\mathrm{a}}$ & Std. & .77851 & .06394 & .11735 & .02271 \\
& Deviation & & & & \\
& Absolute & .131 & .187 & .166 & .215 \\
Most & Extreme & .131 & .187 & .072 & .215 \\
Differences & Positive & .164 & -.154 \\
& Negative & -.072 & -.161 & -.166 & \\
Kolmogorov-Smirnov Z & .806 & 1.154 & 1.021 & 1.324 \\
Asymp. Sig. (2-tailed) & .535 & .139 & .248 & .060 \\
\hline \multicolumn{2}{|l}{ a. Test distribution is Normal. } \\
\hline
\end{tabular}

Sumber: Data Diolah, 2020

Berdasarkan hasil dari uji normalitas kedua yang menggunakan outlier pada SPSS 16.0 diatas, ditemukan 38 data sampel sehingga ditemukan hasil Kolmogrov-Smirnov dari variabel $\mathrm{X}_{1}$ yaitu Likuiditas (CR) sebesar 0,806 dengan Asymp. Sig. 0,535 , variabel $X_{2}$ yaitu Profitabilitas (ROA) sebesar 1,154 dengan Asymp. Sig. 0,139, variabel $\mathrm{X}_{3}$ yaitu leverage (DAR) sebesar 1,021 dengan Asymp. Sig. 0,248, dan variabel Y yaitu agresivitas pajak (ETR) sebesar 1,324 dengan Asymp. Sig. 0,060. Oleh karena nilai Asymp. Sig. dari masingmasing variabel baik variabel independen maupun variabel dependen lebih dari nilai taraf signifikan yaitu $5 \%$ atau 0,05 , maka dapat disimpulkan bahwa data pada penelitian ini berdistribusi normal dan penelitian dapat dilanjutkan.

\section{Hasil Uji Multikolinearitas}

Tabel 6. Uji Multikolinearitas

\begin{tabular}{|l|c|c|}
\hline \multirow{2}{*}{ Variabel } & \multicolumn{2}{|c|}{ Colliniearity Statistics } \\
\cline { 2 - 3 } & Tolerance & VIF \\
\hline CR & 0.639 & 1.564 \\
\hline ROA & 0.987 & 1.013 \\
\hline DAR & 0.634 & 1.578 \\
\hline & & \\
\hline
\end{tabular}

Sumber: Data Diolah, 2020
Berdasarkan hasil dari data diatas, menunjukkan bahwa nilai VIF pada variabel $X_{1}$ atau likuiditas (CR) sebesar 1,564, variabel $X_{2}$ atau profitabilitas (ROA) mempunyai nilai VIF sebesar 1,013 , dan variabel $X_{3}$ atau leverage (DAR) mempunyai nilai VIF sebesar 1,578 . Oleh karena masing - masing variabel diatas memiliki nilai VIF kurang dari 4, maka dapat disimpulkan bahwa tidak terjadi multikolinieritas antar variabel independen.

\section{Hasil Uji Heterokedastisitas}

Tabel 7. Uji Heteroskedastisitas

\begin{tabular}{|c|c|c|c|c|c|c|}
\hline \multicolumn{7}{|c|}{ ANOVA $^{b}$} \\
\hline & Model & $\begin{array}{l}\text { Sum of } \\
\text { Squares }\end{array}$ & df & Mean Square & $\mathrm{F}$ & Sig. \\
\hline \multirow[t]{3}{*}{1} & Regression & .001 & 3 & .000 & \multirow[t]{3}{*}{2.176} & \multirow[t]{3}{*}{$.109^{\circ}$} \\
\hline & Residual & .005 & 34 & \multirow[t]{2}{*}{.000} & & \\
\hline & Total & .005 & 37 & & & \\
\hline & $\begin{array}{l}\text { Predictor } \\
\text { Depende }\end{array}$ & $\begin{array}{l}\text { onstant), } \\
\text { ariable: A }\end{array}$ & $\mathrm{R}$, & $\begin{array}{l}\text { OA, CR } \\
\text { Residu }\end{array}$ & & \\
\hline
\end{tabular}

Sumber: Data Diolah, 2020

Berdasarkan hasil dari uji heteroskedastisitas menggunakan Uji Park diatas, menunjukkan bahwa nilai F sebesar 2,176 dengan nilai sig. 0,109. Oleh karena nilai sig. lebih dari 0,05, maka dapat disimpulkan bahwa pada penelitian ini tidak terjadi heterokedastisitas, dengan kata lain prasyarat analisis regresi terpenuhi.

\section{Hasil Uji Autokorelasi}

Berdasarkan dari hasil uji autokorelasi menggunakan uji Run Test diatas, menujukkan bahwa nilai Aymp. Sig. sebesar 0,250. Oleh karena nilai Asymp. Sig. lebih dari 0,05, maka dapat disimpulkan bahwa tidak terjadi autokorelasi pada data yang digunakan pada penelitian. 
Tabel 8. Uji Autokorelasi

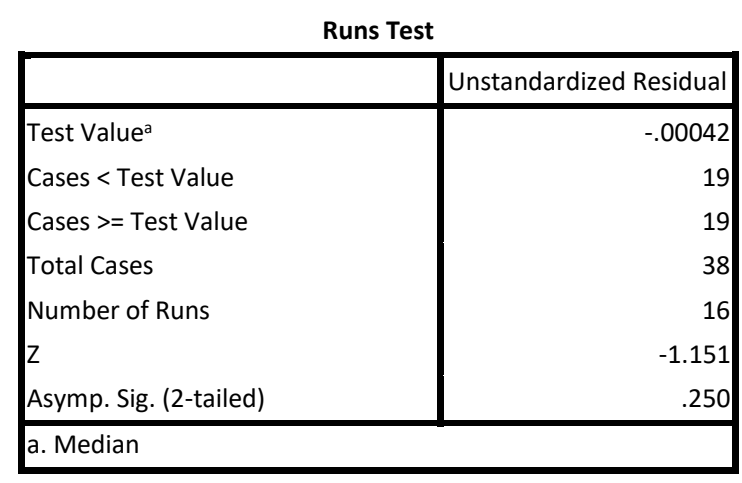

Sumber: Data Diolah, 2020

\subsection{Hasil Analisis Regresi Linier Berganda}

Hasil perhitungan dapat dilihat pada tabel 9 di bawah.

Tabel 9. Hasil Analisis Linear Berganda

\begin{tabular}{|l|l|c|c|c|c|}
\hline \multicolumn{2}{|c|}{} & \multicolumn{2}{|c|}{$\begin{array}{c}\text { Unstandardized } \\
\text { coefficients }\end{array}$} & \\
\cline { 2 - 4 } Model & B & $\begin{array}{c}\text { Std. } \\
\text { Error }\end{array}$ & t & \multirow{2}{*}{ Sig. } \\
\hline \multirow{3}{*}{1.} & (Constant) & 0.327 & 0.026 & 12.513 & 0.000 \\
\cline { 2 - 6 } & CR & -0.017 & 0.005 & -3.184 & 0.003 \\
\cline { 2 - 6 } & ROA & -0.054 & 0.053 & -1.020 & 0.315 \\
\cline { 2 - 6 } & DAR & -0.067 & 0.036 & -1.836 & 0.075 \\
\hline a.Dependent Variable: ETR & & & \\
\hline
\end{tabular}

Sumber: Data Diolah, 2020

Berdasarkan pada tabel 9, maka diperoleh persamaan regresi berganda sebagai berikut : $Y=0,327-0,017 X 1-0,054 X 2-0,067 X 3$.

Nilai konstanta (a) sebesar 0,327. Artinya, jika semua variabel independen yaitu likuiditas (CR), profitabilitas (ROA), dan leverage (DAR) dalam keadaan konstan atau sama dengan 0 , maka nilai variabel dependen yaitu agresivitas pajak (ETR) sebesar 0,327.

Nilai koefisien regresi variabel likuiditas (CR) sebesar $-0,017$. Artinya, jika setiap variabel likuiditas (CR) mengalami kenaikan 1 satuan, maka variabel agresivitas pajak (ETR) mengalami penurunan sebesar 0,017 .
Nilai koefisien regresi variabel profitabilitas (ROA) sebesar $-0,054$. Artinya, jika setiap variabel profitabilitas (ROA) menalami kenaikan 1 satuan, maka variabel agresivitas pajak (ETR) mengalami penurunan sebesar 0,054 .

Nilai koefisien regresi variabel leverage (DAR) sebesar -0,067. Artinya, jika setiap variabel leverage (DAR) mengalami kenaikan 1 satuan, maka variabel agresivitas pajak (ETR) mengalami penurunan sebesar 0,067 .

\subsection{Hasil Uji Hipotesis}

Tabel 10. Hasil Uji t

\begin{tabular}{|c|c|c|}
\hline \multirow{2}{*}{ Model } & $\begin{array}{c}\text { Unstandardized } \\
\text { Coefficients }\end{array}$ & \multirow{2}{*}{ Sig. } \\
\cline { 2 - 2 } & B & 0.000 \\
\hline (Constant) & 0.327 & 0.003 \\
\hline CR & -0.017 & 0.315 \\
\hline ROA & -0.054 & 0.075 \\
\hline DAR & -0.067 & \\
\hline
\end{tabular}

Sumber: Data Diolah, 2020

Pada variabel X1 yaitu likuiditas (CR) diperoleh nilai t hitung sebesar - 3,184 dengan nilai sig. sebesar 0,003 . Oleh karena nilai sig. kurang dari 0,05, maka HO ditolak dan $\mathrm{Ha}$ diterima. Hal tersebut diperkuat dengan nilai $t$ hitung 3,184 > t tabel 2,03224, yang artinya terdapat pengaruh yang signifikan antara likuiditas (CR) terhadap agresivitas pajak (ETR) secara parsial.

Pada variabel $X 2$ yaitu profitabilitas (ROA) diperoleh nilai t hitung sebesar -1,020 dengan nilai sig. sebesar 0,315 . Oleh karena nilai sig. lebih dari 0,05 , maka $\mathrm{HO}$ diterima dan Ha ditolak. Hal tersebut diperkuat dengan nilai t hitung $1,020<$ $\mathrm{t}$ tabel 2,03224 , yang artinya tidak ada pengaruh 
yang signifikan antara profitabilitas (ROA) terhadap agresivitas pajak (ETR) secara parsial.

Pada variabel $\mathrm{X} 3$ yaitu leverage (DAR) diperoleh nilai t hitung $-1,836$ dengan nilai sig. sebesar 0,075 . Oleh karena nilai sig. lebih dari 0,05, maka HO diterima dan Ha ditolak. Hal tersebut diperkuat dengan nilai t hitung $1,836<\mathrm{t}$ tabel 2,03224, yang artinya tidak ada pengaruh yang signifikan antara leverage (DAR) terhadap agresivitas pajak (ETR) secara parsial.

\section{Pembahasan}

\subsection{Likuiditas (CR) terhadap Agresivitas Pajak} (ETR)

Hasil uji t (parsial) untuk variabel likuiditas (CR) sebesar -3,184 dengan nilai sig. 0,003 yang kurang dari 0,05, artinya HO ditolak, maka terdapat pengaruh yang signifikan antara likuiditas (CR) terhadap agresivitas pajak (ETR) secara parsial. Hal tersebut menunjukkan bahwa semakin baik likuiditas perusahaan maka semakin tinggi perusahaan melakukan tindakan agresivitas pajak, karena perusahaan akan lebih mempertahankan arus kasnya untuk memenuhi kewajiban jangka pendeknya.

Hasil ini berbeda dengan hasil penelitian yang dilakukan oleh Suyanto dan Supramono (2012) bahwa dengan likuiditas yang rendah, maka terdapat kemungkinan perusahaan tidak mematuhi peraturan perpajakan dan cenderung agresif terhadap pajak. Namun hasil ini mendukung penelitian yang dilakukan oleh Purwanto et al. (2016) dan Fadli et al. (2016) yang menyatakan bahwa likuiditas berpengaruh negatif dan signifikan terhadap agresivitas pajak.
5.2 Profitabilitas (ROA) terhadap Agresivitas Pajak (ETR)

Hasil uji $t$ (parsial) untuk variabel profitabilitas (ROA) sebesar -1,020 dengan nilai sig. 0,315 yang lebih besar dari 0,05 , artinya $\mathrm{HO}$ diterima, maka tidak ada pengaruh yang signifikan antara profitabilitas (ROA) terhadap agresivitas pajak (ETR) secara parsial. Hal tersebut menunjukkan bahwa semakin tinggi profitabilitas maka tidak terdapat kemungkinan perusahaan melakukan tindakan agresivitas pajak, karena dengan profitabilitas yang tinggi perusahaan mampu membiayai aktivitas perusahaan tanpa melakukan penghindaran pajak.

Hasil ini berbanding terbalik dengan hasil penelitian yang dilakukan oleh Dewinta dan Setiawan (2016) yang menyatakan bahwa perusahaan yang menghasilkan laba besar akan mendapat beban pajak yang besar, sehingga dapat memicu perusahaan untuk melakukan tindakan agresivitas pajak. Namun hasil ini mendukung penelitian yang dilakukan oleh Eta Febrina Fitria (2018) yang menyatakan bahwa profitabilitas tidak berpengaruh terhadap agresivitas pajak.

\subsection{Leverage (DAR) terhadap Agresivitas Pajak (ETR)}

Hasil uji t (parsial) untuk variabel leverage (DAR) sebesar $-1,836$ dengan nilai sig. 0,075 yang lebih besar dari 0,05, artinya HO diterima, maka tidak ada pengaruh yang signifikan antara leverage (DAR) terhadap agresivitas pajak (ETR) secara parsial. Hal tersebut menunjukkan bahwa 
semakin tinggi leverage maka tidak terdapat kemungkinan perusahaan melakukan tindakan agresivitas pajak, karena dengan leverage yang tinggi manajemen perusahaan akan lebih konservatif dalam melaporkan laporan keuangan perusahaan.

Hasil penelitian ini berbeda dengan hasil penelitian yang dilakukan oleh Suyanto dan Supramono (2012) yang menyatakan bahwa dengan leverage yang tinggi maka perusahaan akan cenderung melakukan penghematan pajak. Namun hasil ini mendukung penelitian yang dilakukan oleh Wastam Wahyu Hidayat (2018) dan Ida Bagus Putu Fajar Adisamartha Naniek Noviari (2015) yang menyatakan bahwa tidak terdapat pengaruh antara leverage terhadap agresivitas pajak.

\section{Kesimpulan dan Saran}

Variabel likuiditas (CR) berpengaruh signifikan terhadap agresivitas pajak (ETR) perusahaan manufaktur sub sektor food and beverage periode tahun 2011-2018 secara parsial. Variabel profitabilitas (ROA) tidak berpengaruh signifikan terhadap agresivitas pajak (ETR) perusahaan manufaktur sub sektor food and beverage periode tahun 2011-2018 secara parsial. Variabel leverage (DAR) tidak berpengaruh signifikan terhadap agresivitas pajak (ETR) perusahaan manufaktur sub sektor food and beverage periode tahun 2011-2018 secara parsial.

Saran bagi perusahaan, diharapkan diharapkan untuk menjaga nilai kasnya pada setiap periode, karena dengan arus kas yang baik maka tingkat likuiditas perusahaan perusahaan akan baik. Hal tersebut dapat meminimalisir perusahaan untuk melakukan tindakan agresivitas pajak. Perusahaan diharapkan untuk meningkatkan pendapatan, karena semakin tinggi pendapatan maka perusahaan akan mampu membayar pajak yang sudah seharusnya menjadi kewajiban wajib pajak secara rutin dan dapat menghindari kegiatan agresivitas pajak.

Perusahaan diharapkan untuk menjaga keuangan perusahaan untuk membiayai aktivitas perusahaan baik yang bersumber dari internal maupun eksternal agar selalu rutin memenuhi kewajiban jangka pendek dan kewajiban jangka panjangnya, karena dengan leverage yang tinggi akan menimbulkan beban bunga yang tinggi dan beban bunga tersebut dapat digunakan untuk membayar pajaknya yang mana hal tersebut juga dapat mengurangi tindakan agresivitas pajak pada perusahaan.

Bagi peneliti selanjutnya, diharapkan untuk menambah tahun penelitian dan menggunakan lebih banyak perusahaan, tidak hanya terbatas menggunakan perusahaan sub sektor food and beverage. Peneliti selanjutnya diharapkan untuk menambah variabel independen diluar variabel yang diteliti oleh peneliti, karena masih banyak variabel lain yang dapat mempengaruhi agresivitas pajak.

\section{Daftar Pustaka}

Dewinta, I., \& Setiawan, P. (2016). Pengaruh Ukuran Perusahaan, Umur Perusahaan, Profitabilitas, Leverage, Dan Pertumbuhan Penjualan Terhadap Tax Avoidance. E- 
Jurnal Akuntansi Universitas Udayana, 14(3), 1584-1615.

Fadli, I., Ratnawati, V., \& Kurnia, P. (2016). Pengaruh Likuiditas, Leverage, Komisaris Independen, Manajemen Laba,Dan Kepemilikan Institusional Terhadap Agresivitas Pajak Perusahaan (Studi pada perusahaan manufaktur yang terdaftar di Bursa Efek Indonesia periode 2011-2013). Jurnal Online Mahasiswa Fakultas Ekonomi Universitas Riau, 3(1), 1205-1219.

Frank, M. Z., \& Goyal, V. K. (2011). Trade-off and Pecking Order Theories of Debt. Handbook of Empirical Corporate Finance: Empirical Corporate Finance. Elsevier.

Hanafi, M., \& Halim, A. (2016). Analisis Laporan Keuangan, Edisi Kelima. Yogyakarta: BPFE.

Kraus, A., \& Litzenberger, R. H. (1973). A StatePreference Model Of Optimal Financial Leverage. Journal of Finance, 911-922.

Kurniasih, T., \& Ratna Sari, M. (2013). Pengaruh Return on Assets, Leverage, Corporate Governance, Ukuran Perusahaan Dan Kompensasi Rugi Fiskal Pada Tax Avoidance. Buletin Studi Ekonomi, 18(1), 58-66.

Mardiasmo. (2008). Perpajakan. Yogyakarta: Penerbit Andi.

Mustika, Ratnawati, V., \& Silfi, A. (2017). Pengaruh Corporate Social Responsibility, Ukuran Perusahaan, Profitabilitas, Leverage, Capital Intensity, dan Kepemilikan Keluarga Terhadap Agresivitas Pajak. Jurnal Online Mahasiswa Fakultas
Ekonomi Universitas Riau, 4(1), 1960-1970. Nugraha, N. B., \& Meiranto, W. (2015). Pengaruh Corporate Social Responsibility, Ukuran Perusahaan, Profitabilitas, Leverage Dan Capital Intensity Terhadap Agresivitas Pajak. Diponegoro Journal of Accounting, Vol. 4 No.(PENGARUH CORPORATE SOCIAL RESPONSIBILITY, UKURAN PERUSAHAAN, PROFITABILITAS, LEVERAGE DAN CAPITAL INTENSITY TERHADAP AGRESIVITAS PAJAK), 1-14. http://ejournals1.undip.ac.id/index.php/accounting

Purwanto, A., Yusralaini, \& Susilatri. (2016). Pengaruh Likuiditas, Leverage, Manajemen Laba, Dan Kopensasi Rugi Fiskal Terhadap Agresivitas Pajak Perusahaan Pada Perusahaan Pertanian Dan Pertambangan Yang Terdaftar Di Bursa Efek Indonesia Periode 2011-2013. Jurnal Online Mahasiswa Fakultas Ekonomi Universitas Riau, 3(1), 580-594.

Putri, A. P. (2019). Pengaruh Likuiditas, Leverage, Return on Asset (ROA), Capital Intensity Dan Inventory Intensity Terhadap Agresivitas Pajak. Skripsi. Universitas Islam Negeri Sultan Syarif Kasim.

Sukmawati, F., \& Rebecca, C. (2016). Pengaruh likuiditas dan leverage terhadap agresivitas pajak perusahaan pada perusahaan industri barang konsumsi di Bursa Efek Indonesia Periode 2011-2014. Conference on Management and Behavioral Studies, 498509.

Suyanto, K. D., \& Supramono, S. (2012). 
Likuiditas, leverage, komisaris independen, dan manajemen laba terhadap agresivitas pajak perusahaan. Jurnal Keuangan Dan Perbankan, 16(2), 167-177. 